\title{
Identity Crisis and Solution for Canadian Native Women in Halfbreed
}

\author{
S. Udhayakumar \\ Assistant Professor, Department of English and Comparative Literature \\ Madurai Kamaraj University, Madurai, Tamil Nadu, India \\ D https://orcid.org/0000-0002-3779-3935
}

Manuscript ID:

ENG-2021-09033985

\begin{abstract}
Maria Campbell's autobiography Halfbreed is a self-exploration of herself in the process of her survival pursuit. Her thirty three years of bitter experience with racism and poverty are the major content of her autobiography. Moreover, she has also recorded in the work the sense of alienation in her own land which mainly has made her to feel the traumatic painful experience. Hence, Identity crisis is seen as the major issue that steeps as a block for not only to herself but also to her community women fully towards overcoming their social barriers like poverty, sexism, and racism. Moreover, her self-exploration sets up an ideal to her community women to become stronger and self-reliant. Hence, the paper argues that how Campbell has created her own identity while experiencing problems and issues on her growing up with shameful identity and how she has become the solution to all the halfbreeds like her. The paper further studies that how Campbell has dealt with shame and humiliations which are the threat in achieving empowerment. The paper also analyzes the solution that Campbell has developed by herself despite her negative experiences, what she has learned from the negatives and how she has constructed her own identity which strengthens herself and her community as well.
\end{abstract}

E-ISSN: 2582-3531

Received: 05.04.2021

Keywords: Aboriginals, Identity crisis, Empowerment, Feminism

Maria Campbell is a Canadian Metis writer born in April 26, 1940 in Park Valley, at Saskatchewan. She has tried all genres of writing and so she is called an author, playwright, broadcaster, and filmmaker. She knows four languages like Cree, Michif, Saulteaux and English. She has become the most influential Published: 01.06.2021 person in Canada after facing many hardships in her life. In particular, she has become a political activist and has taken part in many social movements

Citation:

Udhayakumar, S. "Identity Crisis and Solution for Canadian Native Women in Halfbreed." Shanlax International Journal of English, vol. 9, no. 3, 2021, pp. 64-69.

DOI: https://doi.org/10.34293/ english.v9i3.3985 advocating aboriginal rights and rights for women. She has written many influential works and her memoir Halfbreed has earned wide reputation and is prescribed for the Canadian school children in their syllabus. She has produced three children's book People of the buffalo, Little Badger and the Fire Spirit and Riel's People. And her short story Blankets of Shame is well received by all. Her first play Flight depicts the aboriginal practices and has become the first aboriginal theatre production.

Though she meets with a lot of predicaments in her life, she finally becomes an empowered Metis woman. In her memoir Halfbreed, she has mentioned all her life experience explicitly. She is not ashamed to record even the shameful segment of her life. She belongs to a literate family and a family of sufficient income. However, her family turns to a miserable condition after the death of her mother. She has to take care of her siblings as she is the eldest of all when she is at the age of 12. So she has to leave her school education. However she has decided to marry at the age of 15 thinking that her marriage would make her and her siblings' life settled but all is in vain. Her white husband Darrel puts her siblings in a charity house and takes her to Vancouver. 
There she gives birth to a girl child. Later, due to family issues, Maria is abandoned by her husband. She struggles a lot with no money and finally she is forced to do sex work which also ends up with addiction to drug and alcohol. However she joins her daughter in a residential convent. At this point of time, she feels that she has been rejected by everyone. She feels that her disparate condition is the consequence of racism. Finally she goes back to her homeland Saskatchewan and realizes the true nature of her society's problem and resolves to change everything.

Maria being a Metis or halfbreed has met with a lot of troubles despite becoming independent and self-reliant women. Metis are half natives and half whites and so that they are not accepted by neither the natives nor the whites as well. In her family, there has been a mix of races like French, Cree, English, Scottish, and Irish. This mixed identity has created in her a sense of alienation. This troublesome identity has impacted Campbell from her very young age onwards. She says the humiliations she and her family faced because of the identity in these lines,

"My parents and I never shared any aspirations for a future. I never say my father talk back to a white man unless he was drunk. I never saw him or any of our men walk with their heads held high before white people." (Maria Campbell; Halfbreed)

Maria recollects her own experience in her memoir to reveal the bitter truths of her life to the world. Her search for identity at all her growing stages has captured her psychosocial confusions which is conflicting with the social practices of Canadian multicultural society that have resulted in identity crisis.

Erik Homburger Erikson who was a GermanAmerican developmental psychologist and psychoanalyst coined the term identity crisis. The term identity crisis indicates the identity development in human beings through conflict and resolution which has been identified in eight stages of human lifespan. The occurrence of identity crisis is referred as identity cohesion or confusion. People generate ideas of themselves on what others think about them. So one's personality development is based on the above said eight stages. In the process of growing, people experience this psychosocial confusion or crisis that may result in positive or negative outcome. Erikson puts it as the individual's psychological need conflicting with the needs of the society. And hence, crossing of each stage successfully will lead to a healthy personality. In the case of Maria Campbell, her psychological growing is affected by the identity crisis from her early stages. Based on Erikson's stages of psychological development, the first three stages of Maria up to the age of five, she would have completed successfully because she has got her parent's complete love uninterruptedly. But she starts realizing the discriminations at her school when her teachers and fellow students move with her differently. This makes her to feel lack of selfesteem in her. Maria would have struggled to win the approval of the society at that stage. When she fails to expose the demands of the society, she would have developed the sense of inferiority in herself. This is her first time in life facing identity crisis.

Since Campbell belongs to a literate household, she has been grown up with proper educational background. Her mother reads her the works of Shakespeare, Dickens, Walter Scott and Longfellow. Moreover, her grandmother Dubuque has studied in a convent. Her family members have tried to attain her identity by giving her proper education. Her grandmother, Dubuque applies for a residential school for Maria at Beauval, Saskatchewan and she is put in that school at the age of seven. Campbell says that she hates her school life. She states that, "I remember only the ugly black stocking, woolly, and very itchy, and the little red tam I had to wear and how much I hated it." Similarly, A. M. Klein in his poem "Indian Reservation: Caughnawaga" has expressed the same feeling as,

"Childhood, that wished me Indian, hoped that One after school I'd leave the classroom chalk, The varnish smell, the watered dust of the street, To join the clean outdoors and the Iroquois track,"

(A. M. Klein: Indian reservation: Caughnawaga)

Moreover, Maria has experienced loneliness and fear in the school because she was not allowed to speak Cree and even she was punished for speaking that. It is the point of time she realized that the school was not welcoming Metis students and has felt identity crisis. The class has divisions among the students based on their race as Euro-Canadians, 
Natives and Metis. She has said, "We have a lot of fights with the white kids, but finally, after beating them soundly, we were left alone." She has recorded that they see disparities even in food habits. Also she records in her memoir that one teacher often ridicules Metis children for their mistakes and expresses a fake sympathy to them. These things turn her school days more terrible. She is made to feel inferior by the activity of the dominant group. Even the little education has been made nil to her when her mother dies. She has become a school dropout. However she has received honorary doctorate degree after proving herself. Experiencing racial discrimination at the school has made her to feel inferior. The educational system hasn't look up on these aspects of problems faced by students. However, the education system is based on British model, which has focused on the cultural degeneration of other nations and has tried to establish their culture everywhere. White people have educated these underprivileged groups thinking that they are in their barbaric life style. This infusion made other cultures and people to learn whites' culture and their traditions. A. M. Klein rightly points out in his poem Indian reservation: Caughnawaga that it's the cultural dominance over others. He says that the whites by trusting their culture they make others below their power. In the below line, he explains the consequences of

\section{"the men. Beneath their alimentary Shawls}

Sit like black tents their squaws; while for the tourist's Brown pennies scattered at the church door

The ragged papooses, jumb, and bite the dust."

(A. M. Klein: Indian reservation: Caughnawaga)

What spoils a healthy society is discrimination and poverty and this is the case of Canadian multicultural society of Maria's time. The Metis people who are neither whites nor native aboriginals have been discriminated by the whites and the native Indians. Also these people are in the clutches of poverty mainly because of this identity and because of the Canadian government. Campbell identifies discrimination and poverty as the major problems of the Metis people. So as the first Canadian women writer in English, Campbell has tried to voice these themes in her works which capsules the bitter experience of Metis life facing injustice. Her experience with poverty and discrimination is not the problem of her own but all her Metis people suffer from that. And hence, her works have come as a result of her anger against the dominant society and anger against the fate which has caused them to such level. Identity crisis at the level of society is more hellish because it's not like fighting for a single person's identity but for the whole community. It is a kind of journey in the wilderness finding a proper settlement and identity for the Metis people of Canada with no visible sunshine. The work is more like a memoire than an autobiography that it not only talks about Campbell's life but also the lives of her community. The focus of the memoir centers on her family and the society as well. She has tried to picture the bare realities which reveal the agony and pain that her Metis people experiencing under the racial dominance.

Europeans have come and settled in Canada during the 18thcentury. There are Protestant people who have been displaced in their home land. Few have come as explorers and have got settled there. English, French are the major groups of settler occupied Canada. The settlements happened from 18 th century onwards till 19th century and later. They have different religions like protestant and catholic from France and Spain. They marry indigenous women that make the mixed blood. There they have many subgroups within their community. They build their own culture. Centuries past, there are lots of conflicts regarding owning the lands because native people never own land and so nothing left in written document. The Native people have been shifting from the eastern to the central region of Canada. Americans have planned to expand their territory encompassing Canada's territory with in their limit. So Canadian Government tries to protect itself and has created confederated or a united provinces of Canada. The country starts defining their territory. Meanwhile they plundered the lands back from Hutsonbay Company which has been set up during the colonization of British North America.

Metis people lead their life by hunting and trapping but when the lands have been announced by the Canadian government to begranted for the new settlers, some Metis people starts to do farming but they couldn't sustain and be successful since they don't have proper experience in agriculture and 
have lack of investment. Because of this, they have been pushed in the hands of poverty. These people are ill-treated and discriminated by both the whites and natives. Having a Meti identity is very difficult to survey for them. These people have fought for having their lands but eventually they are displaced for their own places. Hence, these people are clutched in cruel hands of the Canadian federal government. They suffer from poverty, alcoholism and abuses. Maria Campbell belongs to this ethnic group where she faces all the oppression caused by the dominant section. Her great grandmother is a Cree lineage and is married to a white, her maternal grandmother is French and the later generations have various mix. Moreover her family suffers from poverty like most other members of her community. She finds that rising to a highest level is impossible with the metis identity. So at many places she feels shame and afraid of revealing her metis identity during her early life.

Maria holds family responsibility at her very young age of 12 since her mother has passed away during a child birth. She has been constantly looking for an identity for her family. Her family is mixed with all bloods that she couldn't find any root and she believes such mixed identity is firm less and shame. She always admires her great grandmother Cheechum who has the Creelineage. Once Maria tells her parents "no-good Halfbreeds" and hearing this, her great grandmother Cheechum scolds her and beats her. She changes the attitude of Maria on that occasion. She says 'I will beat you each time I hear you talk as you did.' Cheechum also has told her about how they have been rebellious once. She is the niece of Gabriel Dumont who has closely associated with Louis Riel during the rebellion for the First Nations Cree and Assiniboine of the District of Saskatchewan against Canadian government in the year 1885 . She told Maria proudly about their bravery such,

"Because they killed Riel they think they have killed us too, but some day, my girl, it will be different." (Halfbreed)

Campbell overcomes the shame about her ancestry after talking with her. She learns many things from her. She probably takes herself as the role model in all her life. These incidents show that she is longing for a concrete identity which she could strongly hold on. The mixed identity makes confusion in Maria's life and makes her less assured and she looks for a strong route to connect with her ancestor and country.

Erikson defines 12 to 18 years as the crucial period and it is the stage an adolescent develops a sense of self and personal identity. At this point of time they explore personal values, beliefs and goals. This part of life is a transitional period from childhood to adulthood and during this prime time one will become more independent and look future in terms of career, relationships, family etc. An adolescent individual will try to accommodate them self with in a society. But in the case of Maria, life is bit challenging that she has to take up many roles in her family. As a mother for her siblings she tries to fulfill all her duties. At this stage, she experiences identity crisis as she is less independent, and her future is blemished as her carrier and goals couldn't been defined by her. However the decision taken for marriage doesn't work well. She feels marriage as the only means to uplift her family from the poverty and all turbulences. But it ends up with failure. All her hopes are failed. She has witnessed failure while establishing a sense of identity within a society and has led to confusion. She was confused by not being sure about her identity and her place in the society.

In the work Emma, Jane Austen depicts that the traditional society considers marriage as a means of settlement for women and by which they gain identity. And the traditional society sees working women as lower than rich women who marry the best suitor. The same concept doesn't work in Maria Campbell's case. She marries a white man to have security, protection and monetary stability but it ends up with disappointment. She has been in a position to take care of her brothers and sisters so she might have thought she could settle her siblings if she is married. But the abusive husband turned her dreams a nightmare. She also might have thought marrying a white man would also give her a white identity but it doesn't work for her. She has taken such decision as experimental one which is a characteristic of an adolescent with identity crisis. However, Maria proved that marriage cannot be a solution to attain identity. 
The marriage life of Maria does not prolong for long time in Vancouver. Having a girl child and being abandoned by her husband she is in utmost helpless state. Her role as a perfect wife couldn't be actualized by her. This sort of confusion and identity crisis has made her to be addicted to drug and alcohol. It also has resulted in establishing negative identity and she eventually has become a sex worker to fight for survival. Her identity crisis has made her life unpleasant. As a single mother, she struggles hard to bring up her child in the wilderness where no hands are there to share her burden. She finally finds a residential school for her daughter and thinks it would be the better choice. When she is in her twenties, she tried to come out from her miserable life condition. By the time she enters the sixth stage of psychosocial development which is identified between the age of 18 and 40. At this stage, people long for intimacy and loving relationship which is completely absent in the life of Maria. This stage would result in safety and care within the relationship. But her unsuccessful completion of this stage makes her to feel isolated, sense of loneliness and depressed. The climax of her trauma is experienced by her during this point of her life. She goes back to her home town witnessing her problems with many. She says,

"Going home after so long a time, I thought that Imight find again the happiness and beauty I had known as a child. But as I walked down the rough dirt road, poked through broken old buildings and though back over the years, I realized that I could never find that here. Like me the land had changed, my people were gone, and if I was to know peace I would have to search within myself. That is when I decided to write about my life."

\section{(Maria Campbell; Halfbreed)}

This line indicates that how she has gained positivity when returned to Saskatchewan. She is resilient and develop snew spirit from her failure.

Maria has become self-reliant, and empowered when she feel the need of a collective responsibility in bringing up her community who have been degenerated by racism. She has returned to Saskatchewan in her twenties and has become a social activist. Her difficult life in Vancouver taught her a life lesson to fight the evils of the society. These life lessons have made her to publish many laws in 1969 which are written for the wellbeing of indigenous people who faces many social issues in the city and outside the city. She witnesses more poverty and abuse happening within her community so she resolves to do something to her people. Eventually, she has recovered from her addiction like drug and alcohol and has showed more involvement in political work. She builds a strong connection to her Metis community. She encounters the problems of other metis women experiencing in their day to day life including drug, alcoholism, sex work, depression. She tries to bring them out of their condition since she has come out from all these negative experiences. By all her efforts, she has made Metis as her positive identity.

\section{Conclusion}

To conclude, one's identity is what they are. Identity is formed by their cultural practices and their personal and professional achievements. The problem arises when their personal identity is conflicting with the needs of the society. It is again the problem with the people thinking what other might think about them. Associating one with their ancestral culture would sometimes give a stronger hold and firmness but people of mixed origin or mixed culture face alienation. Maria, coming from this mixed origin has met with many problems in her life from her young age onwards. The confusion of her identity makes her less confident in facing other in schools and society. However she has learned to face the society from her negative experience. What once is seen as a derogatory or shameful identity is made as their prestigious and positive identity. Maria's revelations of all her life experience explicitly including her poverty, sex work etc. shows that she has broken all the shame and humiliations of her life. In the same way, the Metis identity as shame is broken by her by wearing that identity proudly. Metis is not anymore a shame or humiliation for her. It is a separate ethnic group like whites and other native aboriginal ethnic groups. The confusion of her identity is finally resolved as she has developed matured psychological mindset and she holds clarity in her view towards her society. Thus her identity crisis is eliminated by becoming an empowered and an independent woman in the Metis community. 


\section{References}

Austen, Jane. Emma. Wordsworth Editions, 1992.

Bennett, Russell, and Brown Donna. Anthology of Canadian Literature in English. Oxford University press, 2010.

Campbell, Maria. Half-Breed. Goodread Biographies, 1983.

Erikson, Erik H. Childhood and Society. Norton, 1950.

Heikkila, Verna. "Blankets of Shame: Emotional Representation in Maria Campbell's Halfbreed." The Electronic Journal of the Department of English at the University of Helsinki, vol. 5, 2009.

Karthik, Deep Shikha. First Nations in the Select Works of Maria Campbell. University of Lucknow, 2016.

Klein, A.M. "Indian Reservation: Caughnawaga." Poetry foundation. 1945.

Lawrence, Bonita. "Real" Indians and Others: Mixed-Blood Urban Native Peoples and Indigenous Nationhood. University of Nebraska Press, 2004.

"Maria Campbell." English-Canadian Writers, Athabasca University, http://canadian-writers. athabascau.ca/english/writers/mcampbell/ mcampbell.php

"Maria Campbell." Shattering the Silence: The Hidden History of Indian Residential Schools in Saskatchewan Book. Uregina, www2.uregina. ca/education/saskindianresidentialschools/ beauval-indian-residential-school/mariacampbell/

Mcleod, Saul. “Erik Erikson's Stages of Psychosocial Development." Simply Psychology, 2018.

Sands, Kathleen Mullen. "Collaboration or Colonialism: Text and Process in Native American Women's Autobiographies." MELUS, vol. 22, no. 4, 1997, pp. 39-59.

Swathi, K. “A Subaltern Study of Maria Campbell's Half-Breed." Shanlax International Journal of English, vol. 6, no. S1, 2018, pp. 17-20.

Tobin, Therasa. "Cultural Imperialism." Britannica, 2016.

Tylor, Edward Burnett. Primitive Culture. 1871.

Wahab, E.O., et al. "Cause and Consequence of Rapid Erosion of Cultural Values in a Traditional African Society." Journal of Anthropology, 2012.

\section{Author Details}

Dr. S. Udhayakumar, Assistant Professor, Department of English and Comparative Literature, Madurai Kamaraj University, Madurai, Tamil Nadu, India, Email ID: udhaynimalesh@gmail.com 